\title{
Peptide fragments of bradykinin show unexpected biological activity not mediated by B1 or B2 receptors
}

Igor Souza-Silva ${ }^{1}$, Cristiane de Paula ${ }^{1}$, Lucas Bolais-Ramos ${ }^{1}$, Anderson Santos ${ }^{1}$, Filipe da Silva $^{1}$, Vívian de Oliveira ${ }^{1}$, Isabella da Rocha ${ }^{1}$, Maísa Antunes ${ }^{1}$, Lídia Cordeiro ${ }^{1}$, Vanessa Teixeira $^{1}$, Sérgio Ricardo Scalzo Júnior ${ }^{1}$, Flavio Amaral ${ }^{1}$, Jarbas Resende ${ }^{1}$, Marco Antônio Fontes $^{1}$, Gustavo Menezes ${ }^{1}$, Silvia Guatimosim ${ }^{1}$, Robson Santos ${ }^{1}$, and Thiago Verano-Braga $^{1}$

${ }^{1}$ Federal University of Minas Gerais

January 29, 2021

\begin{abstract}
Background and purpose: Bradykinin [BK-(1-9)] is an endogenous nonapeptide involved in multiple physiological and pathological processes. A long-held belief is that peptide fragments of BK-(1-9) are biologically inactive. Here, we have tested the biological activities of BK-(1-9) and two major peptide fragments in human and animal systems. Experimental Approach: Levels of BK peptides in male Wistar rat plasma were quantified by mass spectrometric methods. Nitric oxide was quantified in human, mouse and rat cells, and loaded with DAF-FM. We used aortic rings from adult male Wistar rats to test vascular reactivity. Changes in blood pressure and heart rate were measured in conscious adult male Wistar rats. Key results: Plasma levels of BK-(1-7) and BK-(1-5) in rats were increased following infusion of BK-(1-9). All tested peptides induced NO production in all cell types tested. However, unlike BK-(1-9), NO production elicited by BK-(1-7) or BK-(1-5) was not inhibited by $\mathrm{B}_{1}$ or $\mathrm{B}_{2}$ receptor antagonists. BK-(1-7) or BK-(1-5) also induced concentration-dependent vasorelaxation of aortic rings, without involving $\mathrm{B}_{1}$ or $\mathrm{B}_{2}$ receptors. In vivo, either intravenous or intra-arterial administration of BK-(1-7) or BK-(1-5) induced similar hypotension response. Conclusions and implications: BK-(1-7) and BK-(1-5) are endogenous peptides present in plasma. They are formed, at least partially, through the BK-(1-9) proteolysis. BK-related peptide fragments show biological activity, not mediated by $\mathrm{B}_{1}$ or $\mathrm{B}_{2}$ receptors. These BK-fragments could constitute new, active components of the kallikrein-kinin system.
\end{abstract}

\section{INTRODUCTION}

Bradykinin [BK-(1-9)] is a nonapeptide of the kallikrein-kinin system (KKS) and was first characterized over 70 years ago (Rochaet al. , 1949), as a potent hypotensive agent in vivo, and to induce a slow contraction of guinea-pig uterus (hencebrady kinin). This biological activity was generated by incubating ox plasma with snake venom (from Bothrops jararaca) or trypsin. A decade later, the nonapeptide BK-(1-9) was purified by (Elliott et al. , 1960) and shown to induce hypotension, slow contraction of smooth muscle and pro-inflammatory effects. Since then, our knowledge of the biochemistry, physiology, and pharmacology of the KKS and BK-(1-9) has greatly increased. In the present context the most important features include (i) the inactivation of BK-(1-9) by plasma kininases I and II (Yang et al. , 1970), (ii) the rapid and extensive inactivation of BK-(1-9) in the pulmonary circulation (Ferreira et al. , 1967), later associated with the angiotensin-converting enzyme (ACE) (Bakhle, 1968; Ferreira et al. , 1970); ii) elucidation of two proteoforms of kininogens (Habal et al. , 1976); iii) identification of des-Arg ${ }^{9}$-BK [BK-(1-8)] as a biologically active component of KKS (Regoli et al. , 1977); iv) cDNA cloning of the constitutive $\mathrm{B}_{2}$ receptor, a selective target for BK-(1-9) (McEachern et al. , 1991); v) cDNA cloning of $\mathrm{B}_{1}$ receptor, a selective target for BK- 
(1-8) (Menkeet al. , 1994) and (vi) FDA approval of the selective $\mathrm{B}_{2}$ receptor antagonist icatibant (Cicardi et al. , 2010) as a treatment for hereditary angiodema.

The bioactivities of the peptide fragments of BK-(1-9) have been mostly overlooked for the past 40 years. In the late 1960s, BK-(1-9) was shown to have a biological half-life of about 17 seconds in blood, being extensively metabolized in a single pass on the pulmonary circulation (clearance of about 80\%) (Ferreira et al. , 1967; Ryan et al. , 1968). Given this short half-life, several studies (Suzukiet al. , 1969; Regoli et al. , 1977; Park et al. , 1978; Redman et al. , 1979; Roch-Arveiller et al. , 1983) aimed at characterizing the potential activity of the fragments of BK-(1-9) in different species and using different protocols. However, the overall conclusion was that the fragments derived from BK-(1-9) were devoid of biological activity, except for the BK-(1-8) (des-Arg $\left.{ }^{9}-\mathrm{BK}\right)$.

Over the last 20 years, several new biological activities for BK-(1-9) have been uncovered (Regoli et al. , 2015; Regoli et al. , 2016), particularly its ability to generate NO, which have considerably increased the range of effects that could be mediated by the nonapeptide. However, the fragments of BK-(1-9) have not been assessed for these new, potential, activities. One problem inherent in such re-assessment of the fragments is the choice of the peptides to study. BK-(1-9) is a substrate for carboxypeptidases (e.g., ACE and ACE2), aminopeptidases (e.g., aminopeptidase P) and endopeptidases (e.g., neutral endopeptidase, now neprilysin), thus generating many different cleavage products (Campbell, 2013; Verano-Braga et al. , 2020). A general conclusion of BK-(1-9) metabolism is that its major proteolytic fragment is the BK-(1-8), which is acknowledged as the only biologically active BK peptide known to date, together with BK-(1-7) and BK-(1-5) that are regarded as biologically inert fragments (Kopylov et al. , 2016; Semis et al. , 2019).

Thus, we present here a re-evaluation of the biological activities exhibited by BK-(1-7) and BK-(1-5), compared with those of the parent nonapeptide BK-(1-9), in a range of in vitro, ex vivo and in vivo systems, using human and rodent tissues. Our results show that, contrary to previous results, these BK-(1-9) fragments are indeed biologically active, stimulating NO production in vitro, and inducing vasorelaxation ex vivo. Such actions were not mediated by either of the kinin $\mathrm{B}_{1}$ or $\mathrm{B}_{2}$ receptors. We also reportin vivo actions of the BK-(1-9) peptide fragments in cardiovascular parameters (arterial blood pressure and heart rate), and under inflammatory conditions.

\section{METHODS}

\subsection{Synthesis, purification and chemical characterization of BK-(1-9), BK-(1-5) and $B_{1}$ re- ceptor antagonist}

BK-(1-9) [RPPGFSPFR], BK-(1-5) [RPPGF] and the B 1 receptor selective antagonist Lys-(des-Arg ${ }^{9}-$ Leu $\left.^{8}\right)$ BK-(1-9) [KRPPGFSPL] were synthesized by solid-phase peptide synthesis employing the Fmoc strategy (Chan et al. , 2000), using NovaSyn-TGA resins (Merck, Kenilworth, NJ, USA). The final unprotected peptides were purified by HPLC using a DiscoveryBIO\& Wide Pore C18 semi-preparative column. Purified products were analysed by MALDI TOF/TOF Autoflex III Smartbeam mass spectrometer (Bruker Daltonics, Hamburg, Germany) for synthesis quality control.

\subsection{Animals}

All animal care and experimental procedures were in accordance with the current edition of the NIH Guide for the Care and Use of Laboratory Animals and were approved by the local Animal Ethical Committee (CEUAUFMG; protocol 213/2016). Adult male Wistar rats (8-12 weeks old; weighting 200-250 g), neonatal male Wistar rats (3-5 days old) and adult male C57Bl/6 mice (8-12 weeks old; weighting 20-24 g) were obtained from the CEBIO-UFMG. $\mathrm{B}_{1}$ and $\mathrm{B}_{2}$ receptor knockout (B1RKO and B2RKO, respectively) male mice were obtained from the animal facility of the Department of Biochemistry and Immunology at UFMG. All animals were housed in standard cages at the animal facility of the Department of Physiology and Biophysics (UFMG), with controlled temperature $\left(22 \pm 2^{\circ} \mathrm{C}\right)$ and under a 12/12 h light-dark cycle. Standard chow and filtered tap water were available ad libitum. Animal studies were done in accordance with the ARRIVE guidelines (Kilkennyet al. , 2010), and with the recommendations made by the editorial board of the British 
Journal of Pharmacology (Lilley et al., 2020). Animals were divided randomly in the experimental groups and the investigator involved in the data analyses was blinded to the experimental conditions.

\subsection{In vivo quantification of BK-(1-9) fragments by multiple reaction monitoring (MRM) mass spectrometry analysis}

Adult male Wistar rats were anesthetized with i.p. administration of urethane $\left(1300 \mathrm{mg} \mathrm{kg}^{-1}\right)$. A polyethylene catheter was inserted into the inferior vena cava through the femoral vein fori.v. administration $(0.1 \mathrm{~mL})$ to add the standards, BK-(1-9) $\left(7 \mu \mathrm{g} \mathrm{kg}{ }^{-1}\right.$ or ${ }^{\sim} 2 \mathrm{nmol}$ per animal) and heavy-isotope labelled $\left[\mathrm{Pro}^{3}\left({ }^{13} \mathrm{C}_{5},{ }^{15} \mathrm{~N}\right)\right]$ -

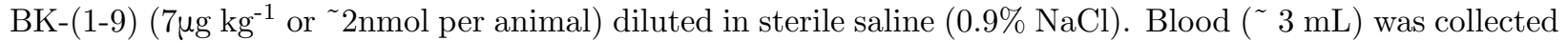
directly from the left ventricle following 15 seconds or 5 minutes of the BK-(1-9) or $\left[\mathrm{Pro}^{3}\left({ }^{13} \mathrm{C}_{5},{ }^{15} \mathrm{~N}\right)\right]$-BK-(19) i.v. administration. Samples from control animals (no peptide administration) were used to provide as zero-time (time $=0 \mathrm{~s}$ ) values. This experimental group was important to define the circulating concentration of any endogenous BK peptide fragments evaluated in this experiment (i.e., BK-(1-7) and BK-(1-5)). The blood was collected in a tube containing the protease inhibitors: $1 \mathrm{mmol} \mathrm{L}^{-1}$ p-hydroxymercuribenzoate, 30 mmol L ${ }^{-1}$ 1,10-phenanthroline, $1 \mathrm{mmol} \mathrm{L}{ }^{-1}$ phenylmethylsulfonyl fluoride (PMSF), $1 \mathrm{mmol} \mathrm{L}{ }^{-1}$ pepstatin A, and $7.5 \%$ EDTA - $140 \mu \mathrm{L} \mathrm{mL}^{-1}$ of blood. Plasma samples were collected by centrifugation $\left(2000 \mathrm{x} g\right.$ at $4^{\circ} \mathrm{C}$ for 20 minutes) and stored at $-80 \mathrm{deg} \mathrm{C}$ until further use. The peptides were extracted from plasma using the HF Bond Elut C18 (Variant, Palo Alto, CA, USA). The C18 resin was activated by 2 sequential washes with $10 \mathrm{~mL}$ of $99 \%$ acetonitrile (ACN) / 0.1\% trifluoroacetic acid (TFA), followed by $10 \mathrm{~mL}$ of $0.1 \%$ TFA. Then, the resin was washed with $3 \mathrm{~mL}$ of $0.1 \%$ TFA / $0.1 \%$ BSA, $10 \mathrm{~mL}$ of $10 \%$ acetonitrile / 0.1\% TFA, and $3 \mathrm{~mL}$ of $0.1 \%$ TFA. The sample $(1.2 \mathrm{~mL})$ was loaded and washed with $20 \mathrm{~mL}$ of $0.1 \%$ TFA and then 3 $\mathrm{mL}$ of $20 \%$ acetonitrile / $0.1 \%$ TFA. The peptides were eluted with $3 \mathrm{~mL}$ of $99 \%$ ACN / $0.1 \%$ TFA into lowbinding polypropylene tubes (Eppendorf, Hamburg, Germany) and dried down using a SpeedVac (Eppendorf, Hamburg, Germany). Each sample was resuspended in $60 \mu \mathrm{L} 0.1 \%$ formic acid (concentration factor of the sample $=20$-fold) and then loaded $(5 \mu \mathrm{L})$ onto the ACQUITY I-Class UPLC system (Waters, Milford, MA, USA) coupled to electrospray ionization (ESI) tandem mass spectrometry (LC-ESI-MS/MS Xevo TQ-S, Waters, Milford, MA, USA). The chromatographic separation was done in a C18 column (ACQUITY UPLC BEH C18 Column, 130Å, $1.7 \mu \mathrm{m}, 2.1 \mathrm{~mm}$ X $100 \mathrm{~mm}$, Waters, Milford, MA, USA) and each chromatography lasted for 5.5 min. Solvent A was made of $0.1 \%$ formic acid in $\mathrm{H}_{2} \mathrm{O}$ and solvent B of $0.1 \%$ formic acid in ACN. The chromatographic gradient was as follows (expressed as \% of solvent B): i) $3-40 \%$ in 3.5 min, ii) $40-99 \%$ in $0.01 \mathrm{~min}$, iii) $99 \%$ for $0.99 \mathrm{~min}$, iv) $99-3 \%$ in $0.01 \mathrm{~min}$, and v) $3 \%$ for $0.99 \mathrm{~min}$. Regarding the MS analysis, the main parameters were as follows: i) capillary $=3.5 \mathrm{kV}$; ii) cone $=20 \mathrm{~V}$; iii) temperature of the desolvation gas (hydrogen) $=550^{\circ} \mathrm{C}$. The collision energy (CE) (argon gas) was tuned for each target peptide spanning from 10 to $20 \mathrm{CE}$. The following transitions were monitored by the MS in the MRM mode. BK-(1-9) [RPPGFSPFR]: 354.4419 .3 and 354.4 408.2. BK-(1-7) [RPPGFSP]: 379.42555 .3 and 379.42 527.4. BK-(1-5) [RPPGF]: 278.1408 .4 and 278.1 166.1. For the heavy-isotope labelled peptides, we used the following transitions. [Pro $\left.{ }^{3}\left({ }^{13} \mathrm{C}_{5},{ }^{15} \mathrm{~N}\right)\right]-\mathrm{BK}-(1-9)$ [RPP $\left.\left({ }^{13} \mathrm{C}_{5},{ }^{15} \mathrm{~N}\right) \mathrm{GFSPFR}\right]: 356.2$ 419.3. [Pro $\left.{ }^{3}\left({ }^{13} \mathrm{C}_{5},{ }^{15} \mathrm{~N}\right)\right]-$ BK-(1-7) [RPP $\left.\left({ }^{13} \mathrm{C}_{5} ;{ }^{15} \mathrm{~N}\right) \mathrm{GFSP}\right]: 382.2$ 561.3. $\left[\operatorname{Pro}^{3}\left({ }^{13} \mathrm{C}_{5} ;{ }^{15} \mathrm{~N}\right)\right]-\mathrm{BK}-(1-5)\left[\operatorname{RPP}\left({ }^{13} \mathrm{C}_{5} ;{ }^{15} \mathrm{~N}\right) \mathrm{GF}\right]: 290.2414 .2$. The calibration curve was obtained using a stock solution containing a mixture of synthetic BK-(1-9), BK-(1$7)$ and BK-(1-5). The applied calibration curve model $(\mathrm{y}=\mathrm{ax}+\mathrm{b})$ proved accurate over the concentration range 10 to $1000 \mathrm{pg} \mathrm{mL}^{-1}\left(\mathrm{r}^{2}=0.968\right)$. The limit of quantitation (LOQ) was below $10 \mathrm{pg}$ per sample. The inter- and intra-variability of this method was $<20 \%$.

\subsection{Nitric oxide measurements in cell culture}

Human glioblastoma cell line U-87 MG was cultured in DMEM-F12 cell media, supplemented by $10 \%$ fetal bovine serum (FBS) (Cultilab, Campinas, Brazil) and 1\% of antibiotic/antimycotic solution (ThermoFisher, Waltham, MA, USA) at $37^{\circ} \mathrm{C}$. Rat neonatal cardiomyocytes were isolated, as previously reported (Guatimosim et al. , 2008). Rat nenonatal cardiomyocytes were maintained with DMEM-F12 cell media supplemented by $10 \% \mathrm{FBS}$ and $1 \%$ of antibiotic/antimycotic solution at $37^{\circ} \mathrm{C}$ until usage. Mice ventricular adult cardiomyocytes were isolated by collagenase type-2 (Worthington, Columbus, OH, USA), as previously described (Rocha-Resende et al. , 2012) and kept in Tyrode media (composition: $140 \mathrm{mM} \mathrm{NaCl} ; 4 \mathrm{mM} \mathrm{KCl}$; 
$1 \mathrm{mM} \mathrm{MgCl} 2 ; 1.8 \mathrm{mM} \mathrm{CaCl}_{2} ; 10 \mathrm{mM}$ Glucose; 5 mM HEPES; $\mathrm{pH}=7.4$ ) until used.

For NO quantification, cells were starved with Hank's Balanced Salt Solution (HBSS) for 1 hour and then loaded with DAF-FM diacetate (Thermo-Fisher, Waltham, MA, USA) at a final concentration of $5 \mu \mathrm{M}$ for 30 minutes. Cells were rinsed with HBSS and stimulated for 15 minutes with BK-(1-9), BK-(1-7) or BK-(1-5), at the final concentration of $100 \mathrm{nM}$, all diluted with sterile saline. Kinin receptors involvement in NO production by the tested peptides was assessed by selective antagonism of $\mathrm{B}_{1}$ and $\mathrm{B}_{2}$ receptors with Lys-(des-Arg ${ }^{9}$-Leu ${ }^{8}$-BK-(1-9) and HOE-140 (Tocris, Bristol, UK), respectively, at a final concentration of $100 \mathrm{nM}$, in sterile saline, prior to stimulation by BK-(1-9) or its fragments. A concentration-response curve was generated by stimulating male neonatal rat cardiac myocytes with BK-(1-9) and its fragments using concentrations of 1, 10 and $100 \mathrm{nM}$, in sterile saline, for 15 minutes. After stimulation under these experimental conditions, cells were fixed with a $4 \%$ paraformaldehyde solution for 15 minutes and then mounted. Fluorescence emitted from cells was captured by either a confocal microscope Zeiss LSM 5 LIVE (Zeiss, Oberkochen, Germany) or a Nikon Eclipse Ti (Nikon, Melville, NY, USA), with $\lambda_{\mathrm{Ex}}=495 \mathrm{~nm}$ and $\lambda_{\mathrm{Ex}}=505 \mathrm{~nm}$. Fluorescence emitted by cells was quantified by ImageJ (Schneider et al. , 2012).

\subsection{Vascular reactivity}

Vascular reactivity of BK-(1-9) and its fragments were assessed as previously described (Rocha-Resende et al. , 2017). Briefly, 8-12 weeks old male Wistar rats were killed by decapitation. The thoracic aorta was quickly dissected, connective and adipose tissues were removed and then the vessel was cut into 3-5mm wide rings. The rings were carefully placed between two stainless-steel stirrups and coupled to an isometric force transducer. The preparations were kept at $37^{\circ} \mathrm{C}$, bathed in Krebs-Henseleit salt solution (118 $\mathrm{mM}$ $\mathrm{NaCl} ; 4.7 \mathrm{mM} \mathrm{KCl} ; 1.17 \mathrm{mM} \mathrm{KH} \mathrm{PO}_{4} ; 1.12 \mathrm{mM} \mathrm{MgSO} 4.7 \mathrm{H}_{2} \mathrm{O} ; 11.2 \mathrm{mM}$ glucose; $25 \mathrm{mM} \mathrm{NaHCO} 3 ; 2.5$ $\mathrm{mM} \mathrm{CaCl} 2.2 \mathrm{H}_{2} \mathrm{O} ; \mathrm{pH}=7.3$ ), lightly bubbled with $95 \% \mathrm{O}_{2} / 5 \% \mathrm{CO}_{2}$. Endothelial cells of some aortic rings were removed by gently rubbing the rings with a thin wire, to evaluate the contribution of endothelial cells to the vasorelaxation. Aortic rings were stabilized for at least 60 minutes under a passive tension of 1.6 g. During the stabilization period, Krebs-Henseleit solution was replaced every 15 minutes and passive tension was corrected to $1.6 \mathrm{~g}$ if needed. Endothelium integrity was assessed by pre-contracting the rings with phenylephrine $(100 \mathrm{nM})$, dissolved in saline. After stabilization of contraction, acetylcholine (ACh, 1 $\mu \mathrm{M})$ was added to induce endothelium-dependent vasorelaxation. Endothelium was considered intact when vasorelaxation mediated by this concentration of ACh was greater than $80 \%$. For experiments using rings without functional endothelium [E (-)], only preparations with no response to ACh were used.

Vasorelaxation mediated by BK-(1-9), BK-(1-7) and BK-(1-5) was assessed in endothelium-intact rings by constructing a concentration-response curve for each peptide, after pre-contraction of rings with phenylephrine $(100 \mathrm{nM})$. Peptide concentrations tested ranged from $1 \mathrm{pM}\left(10^{-12} \mathrm{M}\right)$ to $1 \mu \mathrm{M}\left(10^{-6} \mathrm{M}\right)$. A vehicle (saline) curve was also generated by adding the same volume of saline to the rings, as used with the peptides, as a negative control. Endothelium dependency to those effects was assessed in denuded rings (E $(-))$. The contribution of NO and prostanoids to the vasorelaxation response was assessed by blocking nitric oxide synthases (NOS) and cyclooxygenases (COX) with $\mathrm{N}_{\omega}$-nitro-L-arginine methyl ester (L-NAME) and indomethacin, respectively. Both inhibitors were used at a final concentration of $1 \mu \mathrm{M}$. L-NAME was dissolved in saline and indomethacin was dissolved in DMSO, with further dilutions in saline. The involvement of kinin receptors in vasorelaxation induced by BK-(1-9), BK-(1-7) or BK-(1-5), was assessed by selectively blocking $\mathrm{B}_{1}$ or $\mathrm{B}_{2}$ receptors with Lys-(des-Arg $\left.{ }^{9}-\mathrm{Leu}^{8}\right)$-BK-(1-9), or HOE-140, respectively (final concentration $100 \mathrm{nM}$ ). Inhibitors and antagonists were incubated with preparations for 20 minutes before contraction by phenylephrine.

\subsection{Blood pressure measurements in conscious rats}

The day before blood pressure measurements, 8-12 weeks old male Wistar rats were anesthetized by ketamine/xylazine (60 $\mathrm{mg} \mathrm{kg}^{-1} / 9 \mathrm{mg} \mathrm{kg}^{-1}$, respectively,i.p ). A polyethylene cannula was inserted into the abdominal aorta through the femoral artery for blood pressure measurements and another cannula was inserted into the inferior cava vein through the femoral vein or in the aorta through the left common carotid 
artery for intravenous (i.v. ) or intraarterial (i.a) administration, respectively, of BK-(1-9) and its fragments. The cannulas, filled with saline and closed by metallic pins, were exteriorized in the interscapular region of the animals' backs. Rats were individually housed and left to recover for 24 hours. On the following day, rats were coupled to a pressure transducer and then allowed to stabilize until cardiovascular parameters were stable. The cardiovascular parameters were recorded using the MP 150 Biopac System (Goleta, CA, USA). First, a dose-response relationship was obtained to assess whether BK-(1-9) and its fragments were able to elicit biological responses in vivo. In order to do so, BK-(1-9), BK-(1-7) or BK-(1-5) was administered i.v. as a bolus $(0.1 \mathrm{~mL})$, corresponding to a dose of $2.5 \mathrm{nmol}, 5 \mathrm{nmol}$ or $10 \mathrm{nmol}$ per animal, in sterile saline. Sterile saline was injected at the same volume, as vehicle control. To further explore the in vivo effect mediated by BK-(1-9) and its related fragments, a bolus $(0.1 \mathrm{~mL})$ of each peptide was administered, corresponding to a dose of $10 \mathrm{nmol}$ per animal, in the arterial or venous circulation of adult male rats to assess whether passage through the pulmonary vascular beds would alter the response to these peptides. We also decided to test whether in vivo inhibition of ACE would affect the responses to BK-(1-9), BK-(1-7) and BK-(1-5). After i.v. administration of captopril (5mg kg-1, in sterile saline) and stabilization of cardiovascular parameters, animals were given BK-(1-9) or its related peptides (0.1 mL, $10 \mathrm{nmol}$ per animal, in sterile saline).

\subsection{In vivo plasma extravasation experiment}

Plasma extravasation was performed in $8-12$ weeks old $\mathrm{C} 57 \mathrm{Bl} / 6$ mice as previously reported (Wick et al. , 2018). Briefly, $10 \mathrm{nmol}$ in $10 \mu \mathrm{L}$ of BK-(1-9), BK-(1-7) or BK-(1-5) was injected intradermally in the hind paw and sterile saline was injected in the same volume $(10 \mu \mathrm{L})$ on the contralateral paw as control. Immediately afterwards, Evans' blue (Merck) solution at 2\% was injected intraorbitally for measurement of plasma extravasation. After 30 minutes of peptide administration, mice were killed by cervical dislocation and footpads were dissected. The footpads were dried at $60^{\circ} \mathrm{C}$ for 24 hours and the tissue was weighted. Evans' blue was extracted by formamide for 72 hours under constant stirring and then the absorbance of this final solution was measured by a spectrophotometer at $\lambda=620 \mathrm{~nm}$. Results were expressed as $\mu \mathrm{g}$ of Evans' Blue per mg of dried tissue.

\subsection{In vivo nociceptive assay}

Potential nociceptive reflexes mediated by BK-(1-9), BK-(1-7) and BK-(1-5) were evaluated as previously described (Amaral et al. , 2016). 8-12 weeks old C57Bl/6 mice were submitted to $10 \mu \mathrm{L}$ intradermal hind paw injection of BK-(1-9), BK-(1-7) or BK-(1-5) at a dose of $10 \mathrm{nmol}$. Saline was injected on the contralateral paw as control in the same volume $(10 \mu \mathrm{L})$. Animals were placed individually in acrylic cages with wired floor and submitted to an adaptation period of 20 minutes. Evaluation of mechanical nociceptive reflex was assessed with a pressure-meter (Insight Instruments) by applying a crescent pressure in the hind paw until the mice evoked a dorsiflexion withdrawn reflex. The pressure by which this event occurred, expressed in grams (g) was registered.

\subsection{Relative gene expression by quantitative polymerase chain reaction (qPCR)}

Total RNA from U-87 MG cells, male rat neonatal cardiomyocytes, male murine adult ventricular cardiomyocytes and male rat thoracic aorta was extracted with TRIzol reagent (Thermo-Fisher, Waltham, MA, USA) and cDNA was synthesized using First Strand cDNA Synthesis (Thermo-Fisher, Waltham, MA, USA) kit following the manufacturer's instructions. qPCR was performed in a StepOnePlus Real Time PCR system (Applied Biosystem, Beverly, MA, USA) using Maxima SYBR PCR 2x (Thermo-Fisher, Waltham, MA) and primers (Table 1) (Síntese Biotecnológica, Belo Horizonte, Brazil) at the final concentration of $600 \mathrm{nM}$. The cDNA was diluted in RNAse free water 1:100. Thermal cycling protocol was as follows: i) denaturation at $95^{\circ} \mathrm{C}$ for 5 minutes followed by; ii) 45 cycles of denaturation at $95^{\circ} \mathrm{C}$ for 10 seconds; iii) annealing/extension at $60^{\circ} \mathrm{C}$ for 1 minute. Relative expression of the selected genes was performed by $2^{-\Delta \Delta^{\prime} \tau}$ method (Livak et al. , 2001) using the housekeeper gene S26 as normalizer.

\subsection{Data and statistical analyses}

Experimental design and statistics were as recommended by theBritish Journal of Pharmacology (Curtis 
et al. , 2018). All experiments were done using 5 or 8 independent replicates $(\mathrm{n}=5$ or $\mathrm{n}=8)$. Results are expressed as means \pm SEM. All statistical analyses were performed with GraphPad Prism v.7.0 and $P<0.05$ was considered to show statistical significance between group means. Confocal microscopy $(\mathrm{n}=$ $5)$, plasma extravasation $(n=8)$ and nociception experiments $(n=8)$ were analysed by one-way ANOVA. MS-based plasma peptide quantitation $(\mathrm{n}=5)$, vascular reactivity experiments and mean arterial pressure (MAP, $\mathrm{n}=5)$ and heart rate $(\mathrm{HR}, \mathrm{n}=5)$ measurements were analysed by two-way ANOVA. Relative mRNA quantitation ( $\mathrm{qPCR}, \mathrm{n}=5$ ) data were analysed by unpaired t test (parametric test due to normal distribution).

\subsection{Materials}

Bradykinin fragment BK-(1-7) [RPPGFSP] was purchased from GenOne Biotechnologies (Rio de Janeiro, Brazil). The heavy-isotope labelled BK-(1-9) [H-Arg-Pro- $\left[{ }^{[3} \mathrm{C}_{5} ;{ }^{15} \mathrm{~N}\right]$ Pro-Gly-Phe-Ser-Pro-Phe-Arg-OH; or simply RPP $(*)$ GFSPFR] was purchased from Bachem (Torrance, CA, USA). Unless otherwise stated, all reagents were purchased by Sigma (Saint Louis, MO, USA).

\section{RESULTS}

\subsection{Target mass spectrometry to quantify the BK-(1-9) fragments in plasma from rats}

BK-(1-9) (RPPGFSPFR) is metabolized in the plasma producing a variety of fragments, which potentially include BK-(1-7) (RPPGFSP) and BK-(1-5) (RPPGF). However, one should note that the detection and quantitation of a peptide in the plasma with the same molecular weight (572.66 Da) and amino acid sequence (RPPGF) of BK-(1-5), for example, does not imply that it is indeed the BK-(1-5) as such fragment could be produced from the hydrolysis of other plasma protein / peptide than BK-(1-9). Therefore, we decided to evaluate whether an acute infusion of BK-(1-9) would alter the concentrations for the potential BK-(1-9) fragments in vivo. We did this to ensure that the putative BK-(1-9) fragments were produced from BK-(1-9) metabolization. As shown in Figure 1A, the plasma levels of BK-(1-7) and BK-(1-5) increased after 15 seconds of BK-(1-9) infusion. The highest plasma concentration for BK-(1-7) was observed after 5 minutes of BK-(1-9) infusion while for BK-(1-5), the peak was at 15 seconds of the administration. This result suggests that indeed BK-(1-7) and BK-(1-5) are peptides endogenously derived from BK-(1-9). To confirm this observation, we gave an i.v. infusion of the heavy-isotope labelled $\left[\operatorname{Pro}^{3}\left({ }^{13} \mathrm{C}_{5} ;{ }^{15} \mathrm{~N}\right)\right]$-BK-(1-9) in anesthetized male Wistar rats, using the same experimental conditions as above. The results (Figure 1B) showed a similar response profile, in which a rapid increase of the heavy-isotope labelled $\left[\operatorname{Pro}^{3}\left({ }^{13} \mathrm{C}_{5} ;{ }^{15} \mathrm{~N}\right)\right]$-BK-(1-5) was detected after 15 seconds of $\left[\operatorname{Pro}^{3}\left({ }^{13} \mathrm{C}_{5} ;{ }^{15} \mathrm{~N}\right)\right]$-BK-(1-9) administration while the highest concentration of the heavy-isotope labelled $\left[\operatorname{Pro}^{3}\left({ }^{13} \mathrm{C}_{5} ;{ }^{15} \mathrm{~N}\right)\right]$-BK-(1-7) was observed following 5 min of $\left[\operatorname{Pro}^{3}\left({ }^{13} \mathrm{C}_{5} ;{ }^{15} \mathrm{~N}\right)\right]$-BK-(1-9) administration (Figure 1B).

\subsection{Endogenous BK-(1-9) fragments induce NO production in vitro}

To test whether BK-(1-9) fragments are biologically active, we tested these BK fragments for their ability to induce NO production in different cell types. We used cells from different species (i.e., human, rat and mouse) and known to express the kinin $\mathrm{B}_{1}$ and $\mathrm{B}_{2}$ receptors. As expected, incubation with BK-(1-9) (100 $\mathrm{nM}$ ) increased NO production in immortalized human glioblastoma cells (U-87 MG), neonatal male rat cardiomyocytes and male adult mouse ventricular myocytes. BK-(1-9) fragments, BK-(1-7) and BK-(1-5), at the same concentration, also induced NO production in these cell types (Figure 2).

We then generated a concentration-response curve for NO production mediated by BK-(1-9), BK-(1-7) and BK-(1-5) in neonatal male rat cardiomyocytes. At all concentrations tested (1, 10, and $100 \mathrm{nM})$, BK-(1-9) was able to elicit NO production (Figure 3A). The heptapeptide fragment BK-(1-7) induced NO production in neonatal male rat cardiomyocytes but only at the two higher concentrations (10 and $100 \mathrm{nM})$ in a dosedependent manner (Figure 3B). The pentapeptide metabolite BK-(1-5) (Figure 3C) was able to induce NO production at all concentration tested, including $1 \mathrm{nM}$, but no significant difference was observed between 10 and $100 \mathrm{nM}$. These results suggest that BK-(1-7) and BK-(1-5) are not only metabolites of BK-(1-9) in vivo but, in vitro, they were able to induce NO production in human and rodent cells. 


\subsection{The in vitro NO production induced by BK-(1-7) or BK-(1-5) is not mediated by activation of the kinin receptors}

To evaluate whether BK-(1-7) or BK-(1-5) were agonists at the kinin receptors in vitro, we pre-incubated the cells with a selective antagonist for $\mathrm{B}_{1}$ receptors, Lys-des-Arg ${ }^{9}$-BK-(1-9) or a selective antagonist for $\mathrm{B}_{2}$ receptors, HOE-140. In this manuscript we will also refer to them as B1RB or B2RB, respectively, standing for $\mathrm{B}_{1}$ or $\mathrm{B}_{2}$ receptor blockage. In human glioblastoma cell line (U-87 MG), NO production induced by BK(1-9) was only abolished by the selective $\mathrm{B}_{2}$ receptor antagonist (Figure $\left.4 \mathrm{~A}\right)$. However, the NO production induced by BK-(1-7) (Figure 4B) or BK-(1-5) (Figure 4C) were not affected by neither $\mathrm{B}_{1}$ nor $\mathrm{B}_{2}$ receptor antagonists. We observed the same response profile in neonatal rat cardiomyocytes, where the response to BK-(1-9) (Figure 4D) was abolished by the selective antagonist of $\mathrm{B}_{2}$ receptors. No alteration of $\mathrm{NO}$ production induced by BK-(1-7) (Figure 4E) or BK-(1-5) (Figure 4F) was observed when the cells were incubated with antagonists of $B_{1}$ or $B_{2}$ receptors. These results suggest that the two fragments of BK-(1-9) does not act upon the activation of $\mathrm{B}_{1}$ and/or $\mathrm{B}_{2}$ receptors to induce NO production in vitro.

Male mice with knockout for either $\mathrm{B}_{1}(\mathrm{~B} 1 \mathrm{RKO})$ or $\mathrm{B}_{2}$ receptors $(\mathrm{B} 2 \mathrm{RKO})$ were used to further study our initial results. We found that BK-(1-9) induced NO production only in ventricular cardiomyocytes isolated from B1RKO mice (Figure 4G). On the other hand, BK-(1-7) (Figure 4H) and BK-(1-5) (Figure 4I) induced NO production in ventricular cardiomyocytes isolated from either B1RKO or B2RKO mice.

We employed qPCR to confirm that the cells used in this study expressed the mRNA for $\mathrm{B}_{1}$ and $\mathrm{B}_{2}$ receptors. As shown in Figure 4J, the mRNA for both receptors was highly expressed in U-87 MG cells, although the expression level of $\mathrm{B}_{1}$ receptor mRNA was at least twice higher than the $\mathrm{B}_{2}$ receptor mRNA. The mRNA for $\mathrm{B}_{2}$ receptors, but not that for $\mathrm{B} 1$ receptors, was detected in neonatal male rat cardiomyocytes (Figure $4 \mathrm{~K}$ ) and in male adult mouse ventricular myocytes (Figure $4 \mathrm{~L}$ ). Taken together, these results indicate that BK-(1-7) and BK-(1-5) do not act via $\mathrm{B}_{1}$ or $\mathrm{B}_{2}$ receptors to stimulate NO production in vitro.

\subsection{Effects of the BK-(1-9) fragments on vascular tissue ex vivo}

BK-(1-9) is known to induce vasodilation due to $\mathrm{NO}$ and prostacyclin production in endothelial cells (Marceau et al. , 2020). Given the fact that BK-(1-7) and BK-(1-5) were able to induce NO production in vitro, it was highly likely that these fragments could also promote vasodilation. In aortic rings from male rats, BK-(1-9) induced a concentration-dependent vasorelaxation at lower concentrations and vasoconstriction at higher concentrations (Figure 5A). BK-(1-7) (Figure 5B) and BK-(1-5) (Figure 5C) induced a concentrationdependent vasorelaxation only. The maximum vasorelaxation $\left(\mathrm{E}_{\max }\right)$, expressed as a percentage in relation to the vasoconstriction induced by phenylephrine, was $15 \pm 2 \%$ for BK-(1-9), $19 \pm 2 \%$ for BK-(1-7) and 18 $\pm 2 \%$ for BK-(1-5).

Furthermore, the vascular effect of BK-(1-9) was completely blocked when the endothelial cells were mechanically removed (Figure 5D) or when NOS was pharmacologically blocked by L-NAME (Figure 5G), whereas BK-(1-9)-induced vasorelaxation was only partly blocked by pharmacological inhibition of cyclooxygenases by indomethacin (Figure 5J). BK-(1-7)-induced vasodilation was partly dependent on endothelial integrity (Figure 5E) and prostanoid production (Figure 5K), while NO production was essential for the BK-(1-7)induced vasorelaxation (Figure $5 \mathrm{H})$. BK-(1-5) vasoactivity relied on functional endothelium (Figure 5F), and production of both NO (Figure $5 \mathrm{I}$ ) and prostanoids (Figure 5L). These results suggest that these three peptides, BK-(1-9), BK-(1-7) and BK-(1-5), induced vasorelaxation by different mechanisms.

\subsection{The vascular effects of BK-(1-9) fragments are not mediated by the activation of the kinin receptors}

To assess the relevance of kinin receptors in the vasorelaxation of aortic ring preparations induced by BK-(1-9) fragments, we used pharmacological antagonists of either $\mathrm{B}_{1}$ and $\mathrm{B}_{2}$ receptors, respectively Lys-(des-Arg ${ }^{9}-$ Leu $\left.^{8}\right)$-BK-(1-9) (100 nM) and HOE-140 (100 nM). The vasorelaxant effect induced by BK-(1-9) was abolished by antagonism of either $\mathrm{B}_{2}$ receptors (Figure $6 \mathrm{~A}$ ) or $\mathrm{B}_{1}$ receptors (Figure $6 \mathrm{D}$ ). Interestingly, vasorelaxation induced by BK-(1-7) (Figures $6 \mathrm{~B}$ and $\mathrm{E}$ ) and BK-(1-5) (Figures $6 \mathrm{C}$ and $\mathrm{F}$ ) were not altered in the presence 
of either antagonist of the kinin receptors.

The expression of mRNA for the kinin receptors was also assessed in rat thoracic aorta by qPCR. The mRNA for both $B_{1}$ and $B_{2}$ receptors were detected in the rat thoracic aorta, but the expression of $B_{2}$ receptor mRNA was significantly higher than that of $\mathrm{B}_{1}$ receptor mRNA (Figure $6 \mathrm{G}$ ). Taken together, the results indicate that the vasorelaxation of rat aortic rings induced by BK-(1-7) and BK-(1-5) was independent of the activation of $\mathrm{B}_{1}$ receptor and/or $\mathrm{B}_{2}$ receptors.

\subsection{In vivo effects of the BK-(1-9) fragments}

Vasodilation is often translated in vivo to hypotension as a result of reduced peripheral vascular resistance. Thus, we aimed at assessing whether BK-(1-7) and BK-(1-5) were also able to reduce the arterial blood pressure. When administered intravenously (i.v ) in conscious male rats, BK-(1-9) induced a transient dose-dependent hypotension followed by a transient increase in heart rate (tachycardia) due to baroreflex activation. BK-(1-7) and BK-(1-5) induced a significant hypotension followed by tachycardia but, unlike BK-(1-9), this effect was dose-independent (Figures 7A and B, traces in Supplementary Figure S5). The dose-independent relationship observed for BK-(1-9) fragments could be due to extensive hydrolysis of these peptides in the circulation, mainly in the pulmonary vascular bed. To further explore this, we investigated whether the administration of BK-(1-9) and its fragments on a different vascular bed, thereby bypassing the pulmonary circulation upon their administration, could change the observed responses. Intra-arterial (i.a. ) administration of the BK-(1-9) led to an increased hypotension when compared to i.v. administration (Figures 7C and D, traces on Supplementary Figure S6), since BK-(1-9) is subjected to extensive hydrolysis in the pulmonary circulation (Ferreira et al. , 1967; Ryan et al. , 1968; Ryan et al., 1994) when it is giveni.v. On the other hand, we could not detect any significant difference when BK-(1-7) or BK-(1-5) were i.a. or i.v.administered (Figures 7C and D), suggesting that the BK-(1-9) fragments are somehow more resistant to proteolysis in the pulmonary circulation. As ACE is the main peptidase involved in BK-(1-9) cleavage in vivo and this enzyme is particularly active in the pulmonary circulation (Orfanoset al. , 1999), we tested the effects of ACE inhibition in vivo with captopril (ACEi) on the cardiovascular effects led by BK-(1-9) fragments. As expected, treatment with captopril potentiated the hypotensive response to BK-(1-9) (Figures $7 \mathrm{E}$ and F, traces on Supplementary Figure S7). On the other hand, the cardiovascular effects of the BK-(1-9) fragments were not affected by ACEi (Figures 7E and F, traces on the Supplementary Figure S7). Taken together, our results suggest that the BK-(1-9) fragments induce a discreate hypotension in vivo, although significant when compared with saline administration, which were not affected by the activity of ACE.

Apart from its cardiovascular effects, BK-(1-9) is a potent pro-inflammatory agent (Cayla et al. , 2012). Thus, we evaluated whether the BK-(1-9) fragments could induce nociceptive reflexes and vascular permeability, which are known BK-(1-9) responses. We evaluated nociceptive reflexes in adult male mice following intradermal hind paw injection of BK peptides. Although BK-(1-7) and BK-(1-5) evoked nociceptive responses, the response to BK-(1-9) was significantly greater (Figure 8A). Increased microvascular permeability was assessed by extravasation of Evans' Blue dye, following administration of the BK peptides into the footpad of mice. As expected, BK-(1-9) increased vascular permeability in the footpad, but equivalent molar doses of BK-(1-7) or BK-(1-5) had no significant effect (Figure 8B).

\section{DISCUSSION}

One of the most significant features of the KKS is that its major agonist component, the nonapeptide BK-(1-9) is rapidly and extensively inactivated in vitro or in vivo, in the presence of biological tissues. Such rapid loss of biological activity is shared by many other mediators and neurotransmitters, including NO, prostaglandins, angiotensin II and acetylcholine, and provides an immediate target for pharmacological intervention. Indeed, the isolation of BK-(1-9) (Elliott et al. , 1960) was soon followed by the discovery and characterization of the bradykinin potentiating factor $(\mathrm{BPF})$ as a group of peptides that blocked inactivation of the nonapeptide and potentiated its activities (Ferreira, 1965; Ferreira et al., 1970).

Our re-assessment of the biological activities of two peptide fragments of BK has clearly shown that, in contrast to earlier results (Suzukiet al., 1969; Park et al. , 1978; Redman et al. , 1979; Roch-Arveiller et al. 
, 1983), BK-(1-7) and BK-(1-5) do exhibit a range of biological activities, some of which are similar to those of BK-(1-9) and others which are significantly different from those of the parent nonapeptide. Although, as did BK-(1-9), the two peptide fragments increased NO production in vitro, exhibited vasorelaxant effects ex vivo and induced hypotension in vivo, these biological activities were, unlike those of BK-(1-9), resistant to antagonists of $\mathrm{B}_{1}$ or $\mathrm{B}_{2}$ receptors. Moreover, whereas BK-(1-9) showed, as expected, increased nociception and increased microvascular permeability, the two peptide fragments were clearly less potent nociceptive agents and did not affect microvascular permeability.

\subsection{Which peptide fragments of BK-(1-9) are relevant in vivo?}

Because BK-(1-9) is a substrate for a variety of peptidases, aminopeptidases, carboxypeptidases and endopeptidases, an equal variety of peptide fragments could be generated in vivo. This situation immediately raises the question of which fragments are, in fact, the most likely endogenous peptides formed from BK-(1-9) in vivo. In several earlier studies, BK-(1-8), BK-(1-7) and BK-(1-5) were identified as the major peptide fragments of BK-(1-9) (Murphey et al. , 2000; Marshall et al. , 2002; Ahmad et al., 2006; Ramirez-Molinaet al. , 2006; Kopylov et al. , 2016; Semis et al. , 2019). In the present work, by monitoring the stable isotope-labelled $\left[\mathrm{Pro}^{3}\left({ }^{13} \mathrm{C}_{5} ;{ }^{15} \mathrm{~N}\right)\right]$-BK-(1-9), we were able to detect in vivo production of BK-(1-7) and BK-(1-5), after an infusion of BK-(1-9), thus confirming that these fragments are endogenously produced BK-(1-9) metabolites. Taking all the data together, we could demonstrate that BK-(1-7) and BK-(1-5) were endogenously formed stable metabolites of BK-(1-9) in plasma. As such, it is relevant in the context of the overall response to BK-(1-9) in vivo, to assess the biological activities of these two peptide fragments.

\subsection{Earlier work on biological activities of BK-(1-9) fragments}

The first evidence for important biological activity of a BK-(1-9) metabolite was presented by (Regoli et al. , 1977) who found activity in the octapeptide fragment, BK-(1-8) or des-Arg ${ }^{9}$-BK, and who postulated the existence of two kinin receptors, which was later confirmed by the cloning of the B2 receptor (McEachern et al. , 1991) and the $\mathrm{B}_{1}$ receptor (Menke et al. , 1994). Whereas BK-(1-9) is an agonist at both $\mathrm{B}_{1}$ and B2 receptors, its metabolite BK-(1-8) is a selective agonist of $B_{1}$ receptors. In our work, the activity of either BK-(1-7) or BK-(1-5) on stimulating NO production and inducing vasorelaxation was not affected by either $\mathrm{B}_{1}$ or $\mathrm{B}_{2}$ receptor antagonists. Almost 15 years ago, BK-(1-5) and BK-(1-9) were shown to inhibit $\alpha$-thrombin-induced platelet aggregation and secretion (Hasan et al. , 1996) but BK-(1-5) appeared less potent than BK-(1-9) and both peptides were active at higher concentrations than those we have used (0.1 $-1 \mathrm{mM})$. No further experiments to identify the kinin receptors involved were reported. Later work with BK-(1-5) showed this peptide to increase the survival of rats in a sepsis model and to antagonize the effects of LPS on the contractile response of aortic rings (Morinelli et al. , 2001). The latter effect was observed at $1 \mathrm{nM}$, a concentration similar to those we have used, and these authors discredited the involvement of either $\mathrm{B}_{1}$ or $\mathrm{B}_{2}$ receptors although no data with either receptor antagonist was provided. Moreover, these effects of BK-(1-5) were not endothelium-dependent, excluding a possible mediation by NO. In neither of these earlier reports was the heptapeptide BK-(1-7) studied.

\subsection{Effects on NO production in cells}

We found significant stimulation by BK-(1-7) and BK-(1-5) of NO production in vitro, using neonatal rat and adult mouse cardiomyocytes, as well as human glioblastoma cells. We chose to study cardiomyocytes because the parent peptide BK-(1-9) is known to induce NO production in cardiac myocytes (Oldenburg et al. , 2004) and may contribute to cardiac pre-conditioning (Schoemaker et al. , 2000; Heuschet al. , 2015). We decided to use an immortalized glioblastoma-like cell line derived from humans (U-87 MG) as this cell line expresses mRNA for both $\mathrm{B}_{1}$ and $\mathrm{B}_{2}$ receptors (Uhlen et al. , 2017), which most likely translates to a high density of these receptors in the cell membrane. Although the concentrations of the peptides used were not physiological, they were comparable to those used in other similar pharmacological studies, for example, in reports of Ang-(1-7) (Gomes et al. , 2010), alamandine (Jesus et al. , 2018) and BK-(1-9) actions in vitro (Oldenburget al. , 2004). We acknowledge that a concentration-response curve was needed to confirm that BK-(1-9) fragments action on inducing NO production is not a non-selective event and we 
were able to show that in rat neonatal cardiomyocytes that BK-(1-9) and BK-(1-5) displayed activity at the lowest concentration used $(1 \mathrm{nM})$, whereas BK-(1-7) was active at a higher concentration $(10 \mathrm{nM})$. Taken together, these in vitro results suggest that the two fragments of BK-(1-9) tested were biologically active in stimulating NO production and that these activities were most likely driven by receptor activation and not by a non-specific interaction, given the nanomolar activity of BK-(1-7) and BK-(1-5). Further studies are necessary to identify which target(s) these molecules act upon.

\subsection{Vascular effects ex vivo and in vivo}

Blood pressure is controlled by complex mechanisms that modulate cardiac output and peripheral vascular resistance (see (Guyenet, 2006). The characteristic effect of BK-(1-9) in vivo is a marked hypotension, which was first observed by (Rocha et al. , 1949) and later attributed to vasodilation of systemic vessels, leading to a consequent reduction of peripheral vascular resistance (Leeb-Lundberg et al. , 2005).

In our ex vivo experiments with aortic rings, the two fragments were as effective as the parent nonapeptide, although the contribution of the endothelium, $\mathrm{NO}$ and vasodilator prostanoids to this relaxation differed between the three peptides, implying differences in the mechanisms of vasorelaxation. Another important difference was that the $\mathrm{B}_{1}$ or $\mathrm{B}_{2}$ receptor antagonists were ineffective in blocking the vasorelaxation induced by the fragments, as observed for the stimulation of NO production in cultured cells.

When BK-(1-9) was administered in conscious Wistar rats, we observed the expected transient dosedependent hypotensive response, while the two fragments induced a transient but dose-independent hypotensive response. The acute hypotensive response observed for BK-(1-7) and BK-(1-5), although less prominent than that for BK-(1-9), was similar to that observed for alamandine (Santos et al. , 2019), which is a known cardiovascular modulator of the renin-angiotensin system. However, the acute hypotensive effect mediated by BK-(1-7) and BK-(1-5) was not altered by either ACE inhibition or by bypassing the pulmonary circulation (as per i.a. administration), implying a resistance of the two fragment peptides to ACE. This result may seem counter-intuitive as ACE is the main enzyme responsible for the metabolism, in vivo, of BK-(1-9) and some of its fragments (Kopylovet al. ,2016), but it is also known that BK-(1-9) is a substrate for several other peptidases and it is highly likely in our in vivo model, that both BK-(1-7) and BK-(1-5) are metabolized by peptidases other than ACE. It is important that inhibitors of bradykininases other than ACE are tested to evaluate precisely which enzymes contribute significantly to the cleavage of these metabolites to even smaller products.

\subsection{Effects on inflammation}

When BK-(1-9) or its fragments were administered to conscious rats, we observed augmented locomotion, a sign of nociception. Nociception is associated with inflammation and the KKS is known to play a major role in this pathophysiological process (Leeb-Lundberg et al. , 2005; Marceau et al. , 2020). To assess whether BK-(1-7) and BK-(1-5) played any part in inflammatory events similar to BK-(1-9), we evaluated their activities in two known inflammatory effects of the nonapeptide, nociception (Cayla et al. , 2012) and increased microvascular permeability (Kempe et al. , 2020). We observed that BK-(1-7) and BK-(1-5) increased nociceptive reflexes in $\mathrm{C} 57 \mathrm{Bl} / 6$ mice, but the two fragments were significantly less effective than BK-(1-9). On the other hand, we did not observe increased microvascular permeability mediated by the two BK-(1-9) fragments. Our data suggest that BK-(1-7) and BK-(1-5) would be less potent pro-inflammatory agents than BK-(1-9) and that, in the context of inflammation, cleavage of the nonapeptide to BK-(1-7) and BK-(1-5) would present as a reduction in pro-inflammatory activity. Also, the lack of effects on microvascular permeability could imply that hypotension induced by the fragments in vivo would not be accompanied by oedema, as it is for the parent BK-(1-9). Overall, our data suggest that these peptide fragments may have important outcomes beyond the cardiovascular system, and further and more detailed experiments are needed to evaluate their potential roles in nociception and inflammation. On this regard, since the KSS seems to play an important role in the current SARS-CoV-2 pandemic and its associated disease, COVID-19 (van de Veerdonk et al. , 2020; Verano-Bragaet al. , 2020), and some COVID-19 symptoms like thrombosis, lung inflammation and pulmonary edema may be a direct consequence of the so-called "bradykinin storm" 
(Garvin et al. , 2020), the relevance of BK-(1-7) and BK-(1-5) in COVID-19 should also be studied.

\section{CONCLUSION}

Our study shows that two peptide fragments of BK-(1-9) - BK-(1-7) and BK-(1-5) - have significant biological activity in human, rat and mouse cell lines. The cardiovascular response triggered by these fragments seems to be comparable with that of BK-(1-9). However, these peptides exhibit significantly less pro-inflammatory responses than those elicited by BK-(1-9). The observed biological activity for BK-(1-7) and BK-(1-5) is mediated by receptors other than the canonical kinin $\mathrm{B}_{1}$ and $\mathrm{B}_{2}$ receptors, implying new pharmacological target(s) yet to be characterized for this peptide mediator system. We suggest that the KKS, like the RAS, is now showing signs of much greater complexity than previously described, in terms of active components and possible targets. Such changes would allow the KKS to fine-tune physiological and pathological processes, including those of the cardiovascular system, inflammation and nociception.

\section{ACKNOWLEDGMENTS}

We are grateful for the excellent technical support of Adriana Campezatto Raabe from the Laboratório Multiusuários de Proteômica(LMProt) and Centro de Laboratórios Multiusuários do Instituto de Ciências Biológicas (CELAM) at the Universidade Federal de Minas Gerais, and Jamil Silvano de Oliveira from the Departamento de Bioquímica e Imunologia at the Universidade Federal de Minas Gerais. We also acknowledge the Centro de Aquisição e Processamento de Imagens (CAPI-UFMG) for confocal microscopy experiments and the Laboratório Multiusuários de Proteômica(LMProt) for mass spectrometry analyses.

\section{FUNDING}

This work was fully supported by grants from the Conselho Nacional de Desenvolvimento Cientifico $e$ Tecnológico (CNPq) (\#421021/2016-0, and \#309122/2019-8), and from the Fundação de Amparo a Pesquisa de Minas Gerais (FAPEMIG) (\#CBB-APQ-03242-16). We also acknowledge the support of the Coordenação de Aperfeiçoamento de Pessoal de Nivel Superior (CAPES).

\section{STATEMENT OF CONTRIBUTION}

I.M.S.S.: Experimental design, peptide synthesis, confocal cell imaging, vascular reactivity, manuscript preparation and revision; V.P.T., S.R.A.S.J.: Isolation of cardiac myocytes; A.K.S.: qPCR analysis; V.L.S.O., data acquisition from inflammatory and nociceptive in vivo experiments; I.D.R., C.A.P: In vivo arterial blood pressure experiments; M.M.A: Data acquisition on confocal cell imaging. L.P.B.C.: Peptide synthesis. F.A.A., J.M.R., G.B.M., M.A.P.F., S.G. and R.A.S.: Experimental design, results discussion and revision of the manuscript. T.V.B.: Experimental design, results discussion, revision and manuscript submission.

\section{CONFLICT OF INTEREST}

None declared.

\section{REFERENCES}

Ahmad M, Zeitlin IJ, Parratt JR, Pitt AR (2006). Degradation of bradykinin, a cardioprotective substance, during a single passage through isolated rat-heart. Archives of pharmacal research 29: 241-248.

Amaral FA, Bastos LF, Oliveira TH, Dias AC, Oliveira VL, Tavares LD, et al. (2016). Transmembrane TNF-alpha is sufficient for articular inflammation and hypernociception in a mouse model of gout.European journal of immunology 46: 204-211.

Bakhle YS (1968). Conversion of angiotensin I to angiotensin II by cell-free extracts of dog lung. Nature 220: 919-921.

Campbell DJ (2013). Bradykinin Peptides. In: Kastin AJ (ed).Handbook of Biologically Active Peptides , 2nd edn. p^pp 1386-1393. 
Cayla C, Labuz D, Machelska H, Bader M, Schafer M, Stein C (2012). Impaired nociception and peripheral opioid antinociception in mice lacking both kinin B1 and B2 receptors. Anesthesiology116: 448-457.

Chan WC, White PD (2000). Fmoc Solid Phase Peptide Synthesis - A Practical Approach . edn. Oxford University Press.

Cicardi M, Banerji A, Bracho F, Malbran A, Rosenkranz B, Riedl M, et al. (2010). Icatibant, a new bradykinin-receptor antagonist, in hereditary angioedema. The New England journal of medicine363: 532541 .

Curtis MJ, Alexander S, Cirino G, Docherty JR, George CH, Giembycz MA, et al. (2018). Experimental design and analysis and their reporting II: updated and simplified guidance for authors and peer reviewers. British journal of pharmacology 175: 987-993.

Elliott DF, Horton EW, Lewis GP (1960). Actions of pure bradykinin. The Journal of physiology 153: 473-480.

Ferreira SH (1965). A Bradykinin-Potentiating Factor (Bpf) Present in the Venom of Bothrops Jararca. British journal of pharmacology and chemotherapy 24: 163-169.

Ferreira SH, Vane JR (1967). The disappearance of bradykinin and eledoisin in the circulation and vascular beds of the cat. British journal of pharmacology and chemotherapy 30: 417-424.

Ferreira SH, Greene LH, Alabaster VA, Bakhle YS, Vane JR (1970). Activity of various fractions of bradykinin potentiating factor against angiotensin I converting enzyme. Nature 225: 379-380.

Garvin MR, Alvarez C, Miller JI, Prates ET, Walker AM, Amos BK, et al. (2020). A mechanistic model and therapeutic interventions for COVID-19 involving a RAS-mediated bradykinin storm. eLife 9 .

Gomes ER, Lara AA, Almeida PW, Guimaraes D, Resende RR, Campagnole-Santos MJ, et al. (2010). Angiotensin-(1-7) prevents cardiomyocyte pathological remodeling through a nitric oxide/guanosine 3',5'cyclic monophosphate-dependent pathway. Hypertension55: 153-160.

Guatimosim S, Amaya MJ, Guerra MT, Aguiar CJ, Goes AM, Gomez-Viquez NL, et al. (2008). Nuclear $\mathrm{Ca} 2+$ regulates cardiomyocyte function. Cell calcium 44: 230-242.

Guyenet PG (2006). The sympathetic control of blood pressure.Nature reviews. Neuroscience 7: 335-346.

Habal FM, Movat HZ (1976). Kininogens of human plasma. Seminars in thrombosis and hemostasis 3: 27-42.

Hasan AA, Amenta S, Schmaier AH (1996). Bradykinin and its metabolite, Arg-Pro-Pro-Gly-Phe, are selective inhibitors of alpha-thrombin-induced platelet activation. Circulation 94: 517-528.

Heusch G, Botker HE, Przyklenk K, Redington A, Yellon D (2015). Remote ischemic conditioning. Journal of the American College of Cardiology 65: 177-195.

Jesus ICG, Scalzo S, Alves F, Marques K, Rocha-Resende C, Bader M, et al. (2018). Alamandine acts via MrgD to induce AMPK/NO activation against ANG II hypertrophy in cardiomyocytes. American journal of physiology. Cell physiology 314: C702-C711.

Kempe S, Fois G, Brunner C, Hoffmann TK, Hahn J, Greve J (2020). Bradykinin signaling regulates solute permeability and cellular junction organization in lymphatic endothelial cells. Microcirculation27: e12592.

Kilkenny C, Browne WJ, Cuthill IC, Emerson M, Altman DG (2010). Improving bioscience research reporting: the ARRIVE guidelines for reporting animal research. PLoS biology 8: e1000412.

Kopylov AT, Myasoedov NF, Dadayan AK, Zgoda VG, Medvedev AE, Zolotarev YA (2016). Use of deuterium labeling by high-temperature solid-state hydrogen-exchange reaction for mass spectrometric analysis of bradykinin biotransformation. Rapid communications in mass spectrometry : RCM 30: 1283-1294. 
Leeb-Lundberg LM, Marceau F, Muller-Esterl W, Pettibone DJ, Zuraw BL (2005). International union of pharmacology. XLV. Classification of the kinin receptor family: from molecular mechanisms to pathophysiological consequences. Pharmacological reviews 57: 27-77.

Lilley E, Stanford SC, Kendall DE, Alexander SPH, Cirino G, Docherty JR, et al. (2020). ARRIVE 2.0 and the British Journal of Pharmacology: Updated guidance for 2020. British journal of pharmacology 177: 3611-3616.

Livak KJ, Schmittgen TD (2001). Analysis of relative gene expression data using real-time quantitative PCR and the 2(-Delta Delta C(T)) Method. Methods 25: 402-408.

Marceau F, Bachelard H, Bouthillier J, Fortin JP, Morissette G, Bawolak MT, et al. (2020). Bradykinin receptors: Agonists, antagonists, expression, signaling, and adaptation to sustained stimulation.International immunopharmacology 82: 106305.

Marshall P, Heudi O, McKeown S, Amour A, Abou-Shakra F (2002). Study of bradykinin metabolism in human and rat plasma by liquid chromatography with inductively coupled plasma mass spectrometry and orthogonal acceleration time-of-flight mass spectrometry. Rapid communications in mass spectrometry : RCM 16: $220-228$.

McEachern AE, Shelton ER, Bhakta S, Obernolte R, Bach C, Zuppan P, et al. (1991). Expression cloning of a rat B2 bradykinin receptor.Proceedings of the National Academy of Sciences of the United States of America 88: 7724-7728.

Menke JG, Borkowski JA, Bierilo KK, MacNeil T, Derrick AW, Schneck KA, et al. (1994). Expression cloning of a human B1 bradykinin receptor. The Journal of biological chemistry 269:21583-21586.

Morinelli TA, Webb JG, Jaffa AA, Privitera PJ, Margolius HS (2001). A metabolic fragment of bradykinin, Arg-Pro-Pro-Gly-Phe, protects against the deleterious effects of lipopolysaccharide in rats. The Journal of pharmacology and experimental therapeutics 296: 71-76.

Murphey LJ, Hachey DL, Oates JA, Morrow JD, Brown NJ (2000). Metabolism of bradykinin In vivo in humans: identification of BK1-5 as a stable plasma peptide metabolite. The Journal of pharmacology and experimental therapeutics 294: 263-269.

Oldenburg O, Qin Q, Krieg T, Yang XM, Philipp S, Critz SD, et al.(2004). Bradykinin induces mitochondrial ROS generation via NO, cGMP, PKG, and mitoKATP channel opening and leads to cardioprotection. American journal of physiology. Heart and circulatory physiology286: H468-476.

Orfanos SE, Langleben D, Khoury J, Schlesinger RD, Dragatakis L, Roussos C, et al. (1999). Pulmonary capillary endothelium-bound angiotensin-converting enzyme activity in humans. Circulation99: 1593-1599.

Park WK, St-Pierre SA, Barabe J, Regoli D (1978). Synthesis of peptides by the solid-phase method. III. Bradykinin: fragments and analogs. Canadian journal of biochemistry 56: 92-100.

Ramirez-Molina C, Heudi O, Pullen M, Marshall PS (2006). Study of bradykinin metabolism by rat lung tissue membranes and rat kidney brush border membranes by HPLC with inductively coupled plasma-mass spectrometry and orthogonal acceleration time-of-flight mass spectrometry. Journal of peptide science : an official publication of the European Peptide Society 12: 220-226.

Redman LW, Regoli D, Tustanoff ER (1979). Immunological and biological activities of fragments and analogs of bradykinin. Canadian journal of biochemistry 57: 529-539.

Regoli D, Gobeil F, Jr. (2015). Critical insights into the beneficial and protective actions of the kallikreinkinin system. Vascular pharmacology 64: 1-10.

Regoli D, Gobeil F (2016). Kinins and peptide receptors.Biological chemistry 397: 297-304. 
Regoli D, Barabe J, Park WK (1977). Receptors for bradykinin in rabbit aortae. Canadian journal of physiology and pharmacology55: 855-867.

Roch-Arveiller M, Caranikas S, Regoli D, Giroud JP (1983). Effects of bradykinin and some of its fragments on smooth muscles and chemotaxis. European journal of pharmacology 88: 99-103.

Rocha-Resende C, Leao NM, de Lima ME, Santos RA, Pimenta AMC, Verano-Braga T (2017). Moving pieces in a cryptomic puzzle: Cryptide from Tityus serrulatus Ts3 Nav toxin as potential agonist of muscarinic receptors. Peptides 98: 70-77.

Rocha-Resende C, Roy A, Resende R, Ladeira MS, Lara A, de Morais Gomes ER, et al. (2012). Non-neuronal cholinergic machinery present in cardiomyocytes offsets hypertrophic signals. J Mol Cell Cardiol53: 206-216.

Rocha ESM, Beraldo WT, Rosenfeld G (1949). Bradykinin, a hypotensive and smooth muscle stimulating factor released from plasma globulin by snake venoms and by trypsin. The American journal of physiology 156 : 261-273.

Ryan JW, Roblero J, Stewart JM (1968). Inactivation of bradykinin in the pulmonary circulation. The Biochemical journal 110:795-797.

Ryan JW, Berryer P, Chung AY, Sheffy DH (1994). Characterization of rat pulmonary vascular aminopeptidase $\mathrm{P}$ in vivo: role in the inactivation of bradykinin. The Journal of pharmacology and experimental therapeutics 269: 941-947.

Santos RAS, Oudit GY, Verano-Braga T, Canta G, Steckelings UM, Bader M (2019). The renin-angiotensin system: going beyond the classical paradigms. American journal of physiology. Heart and circulatory physiology 316: H958-H970.

Schneider CA, Rasband WS, Eliceiri KW (2012). NIH Image to ImageJ: 25 years of image analysis. Nature methods 9: 671-675.

Schoemaker RG, van Heijningen CL (2000). Bradykinin mediates cardiac preconditioning at a distance. American journal of physiology. Heart and circulatory physiology 278: H1571-1576.

Semis M, Gugiu GB, Bernstein EA, Bernstein KE, Kalkum M (2019). The Plethora of AngiotensinConverting Enzyme-Processed Peptides in Mouse Plasma. Analytical chemistry 91: 6440-6453.

Suzuki K, Abiko T, Endo N (1969). Synthesis of every kinds of peptide fragments of bradykinin. Chemical \& pharmaceutical bulletin $17:$ 1671-1678.

Uhlen M, Zhang C, Lee S, Sjostedt E, Fagerberg L, Bidkhori G, et al. (2017). A pathology atlas of the human cancer transcriptome.Science 357.

van de Veerdonk FL, Netea MG, van Deuren M, van der Meer JW, de Mast Q, Bruggemann RJ, et al. (2020). Kallikrein-kinin blockade in patients with COVID-19 to prevent acute respiratory distress syndrome.eLife 9.

Verano-Braga T, Martins ALV, Motta-Santos D, Campagnole-Santos MJ, Santos RAS (2020). ACE2 in the renin-angiotensin system. Clinical science 134: 3063-3078.

Wick MJ, Harral JW, Loomis ZL, Dempsey EC (2018). An Optimized Evans Blue Protocol to Assess Vascular Leak in the Mouse. Journal of visualized experiments : JoVE .

Yang HY, Erdos EG, Levin Y (1970). A dipeptidyl carboxypeptidase that converts angiotensin I and inactivates bradykinin. Biochimica et biophysica acta 214: 374-376.

\section{Hosted file}

3_Table.pdf available at https://authorea.com/users/392620/articles/506412-peptide-fragmentsof-bradykinin-show-unexpected-biological-activity-not-mediated-by-b1-or-b2-receptors 

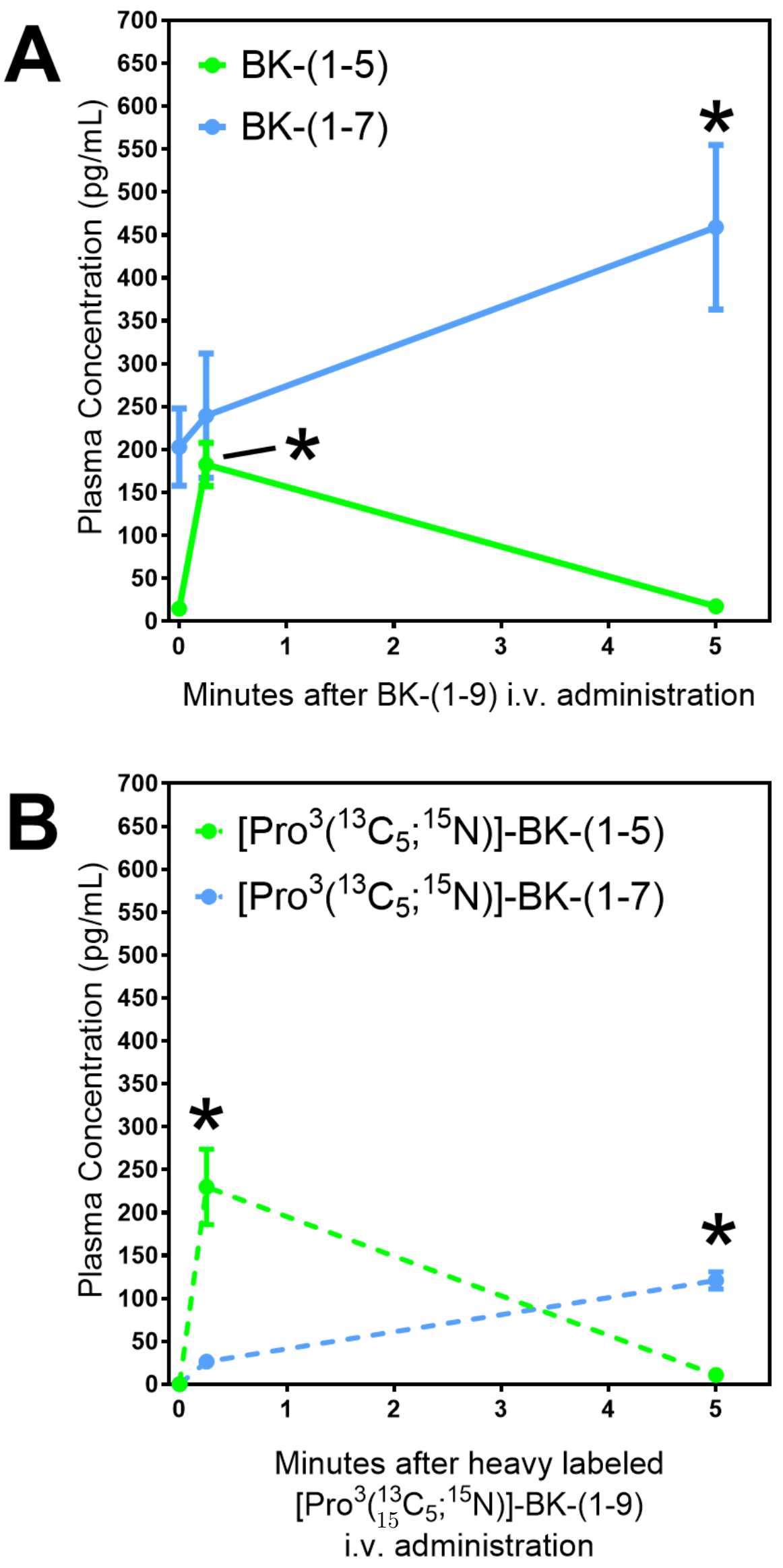

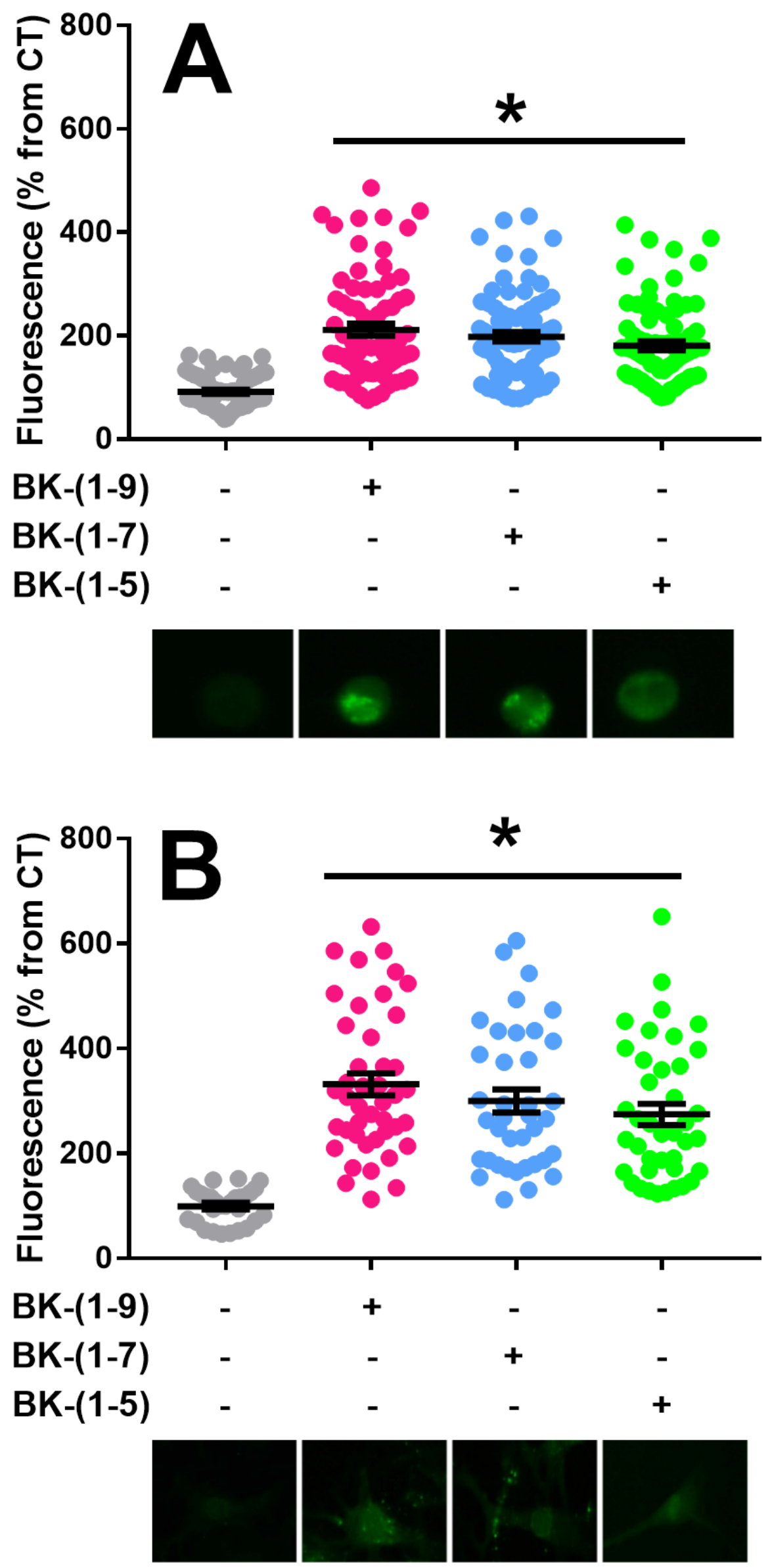


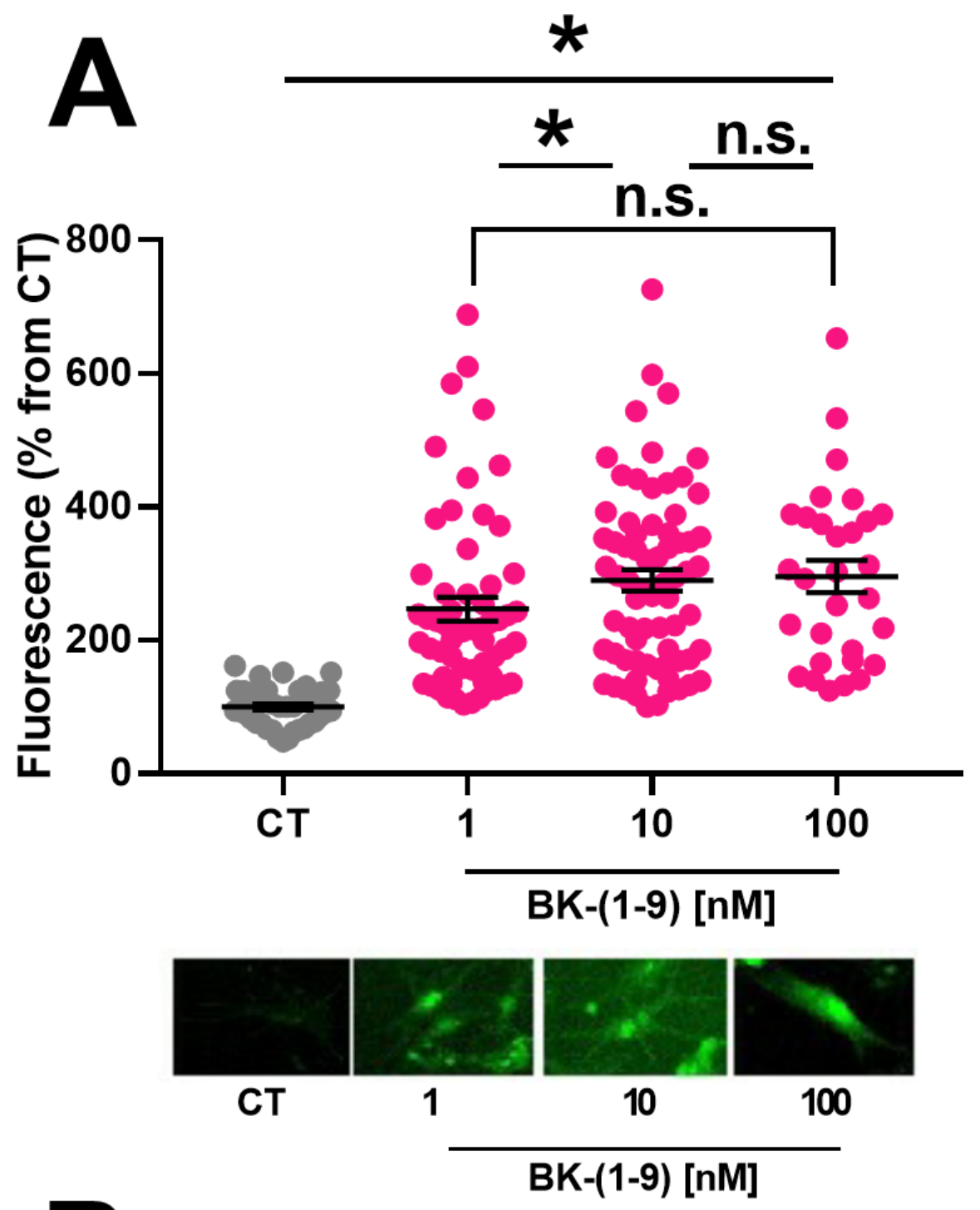

\section{B}

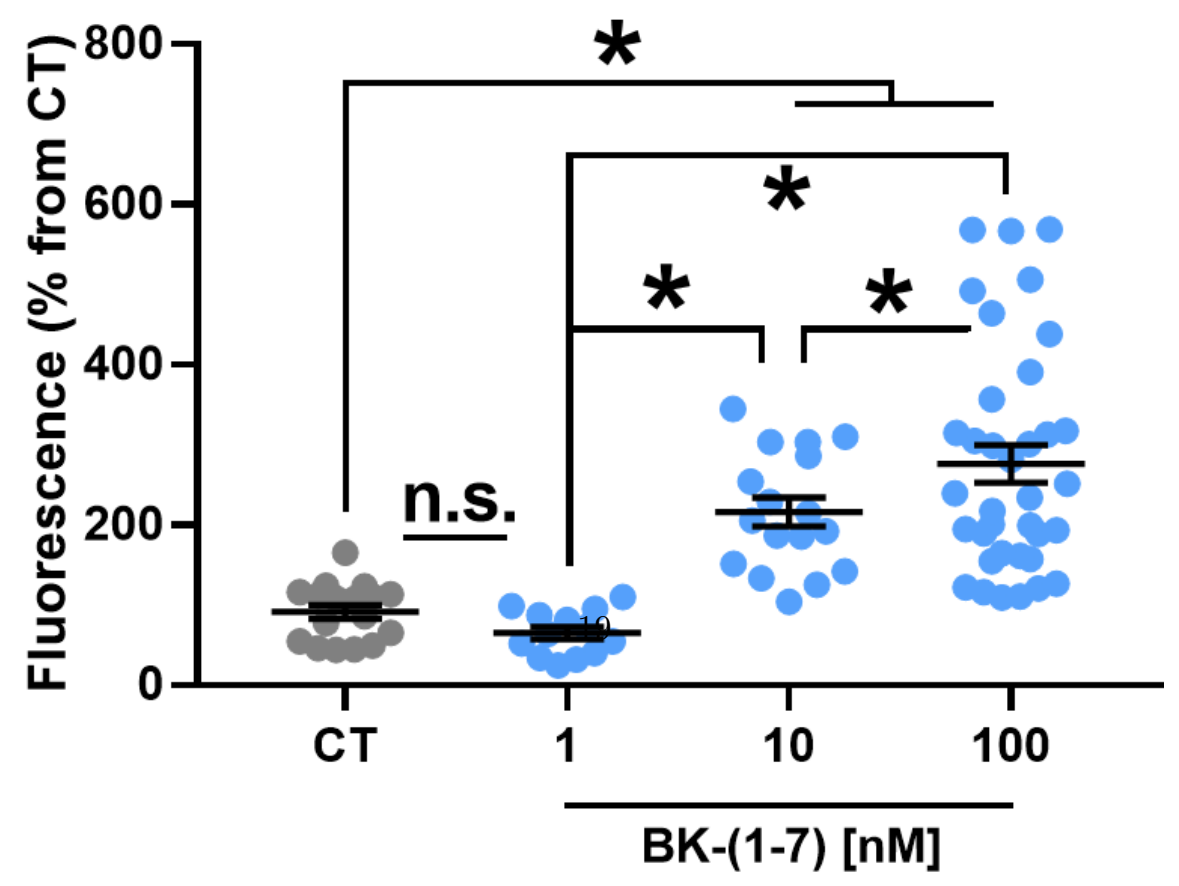




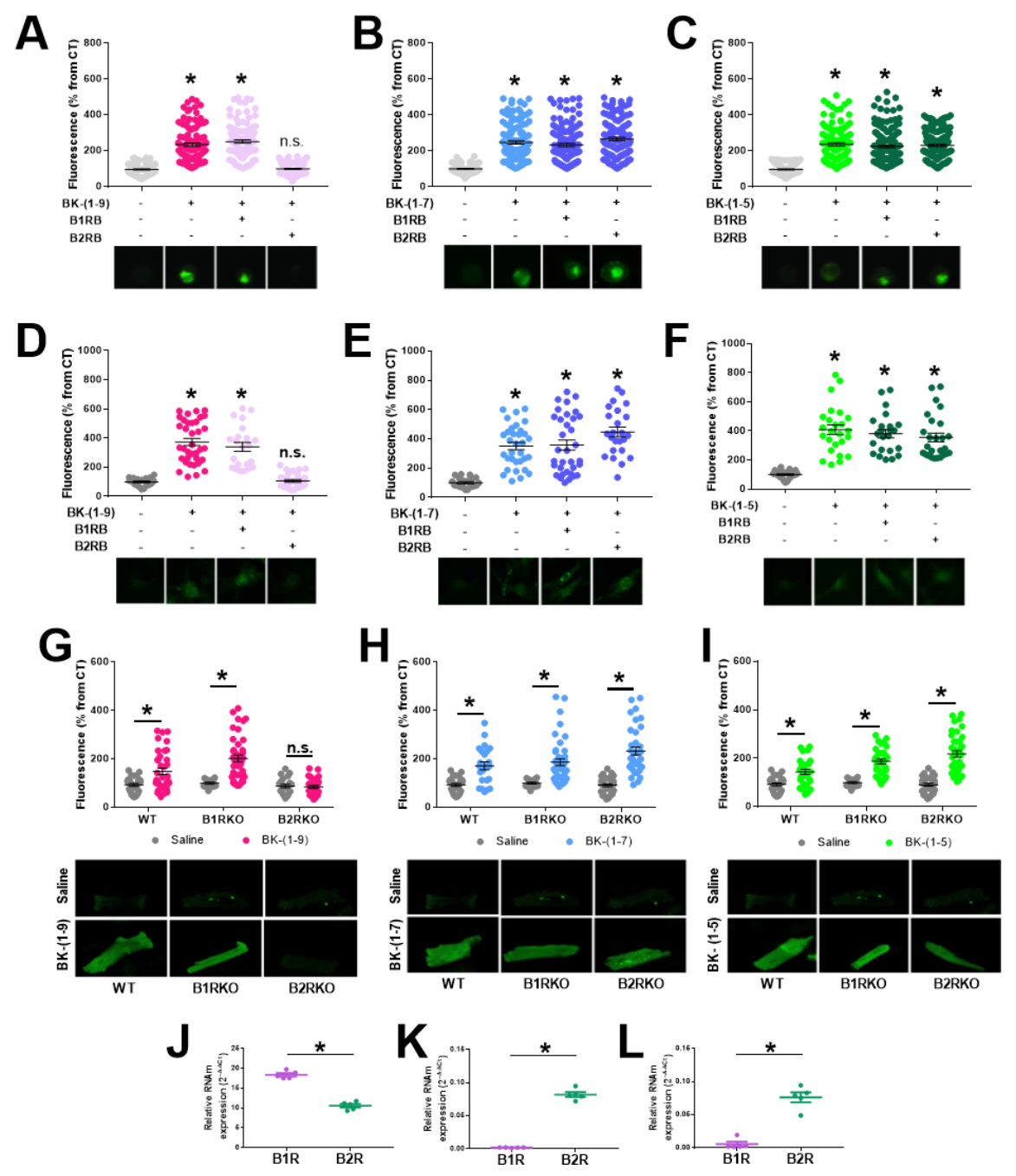




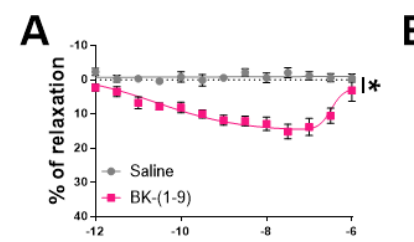

$\log [$ BK-(1-9) in M ]

D

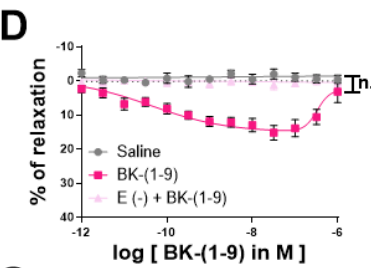

G
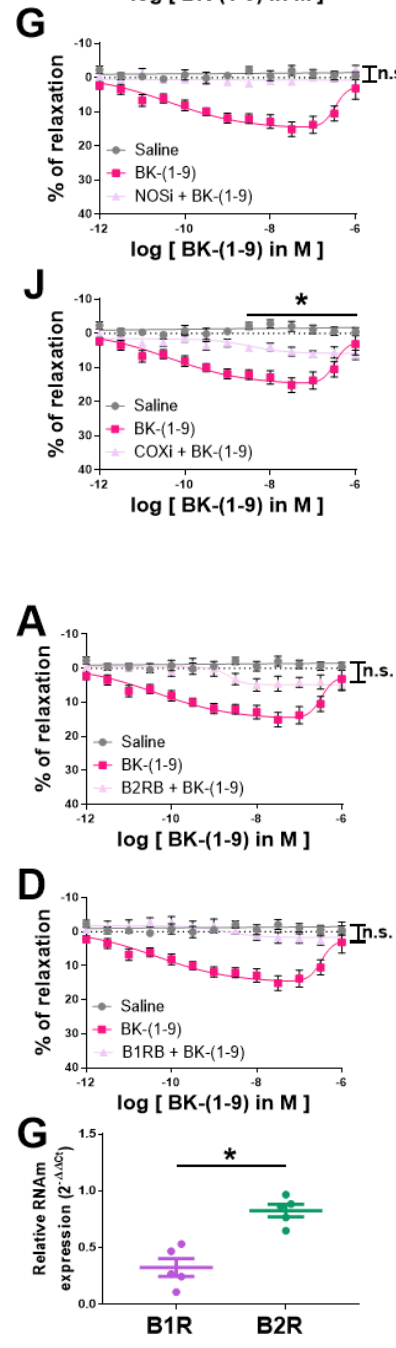

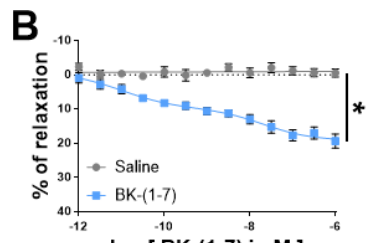

$\log [$ BK-(1-7) in M ]

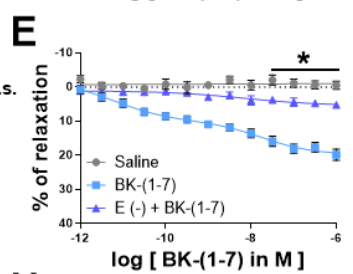

$\mathrm{H}$

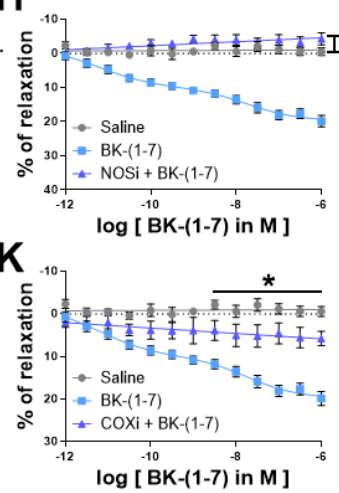

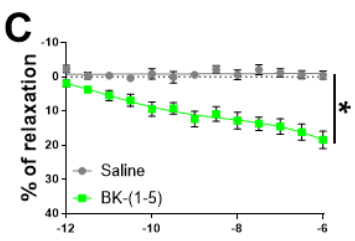

$\log [$ BK-(1-5) in M ]

F

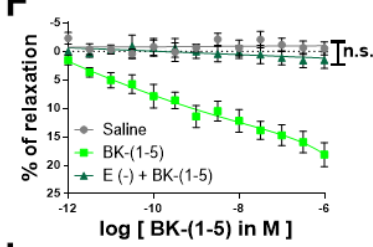

I

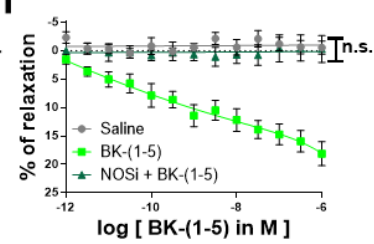

L

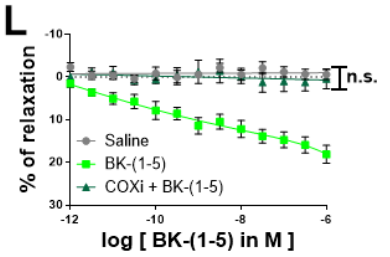

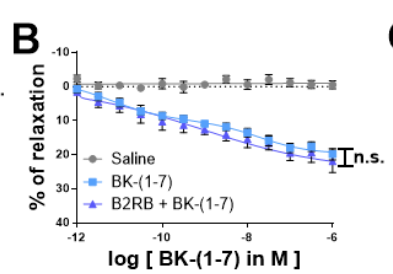

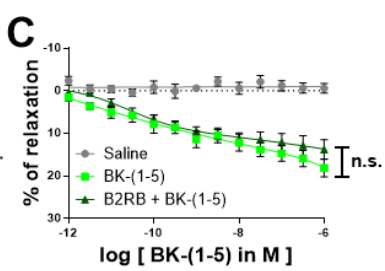

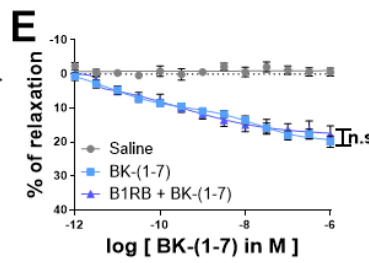

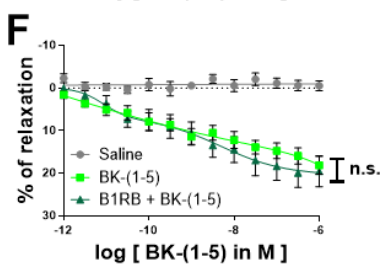



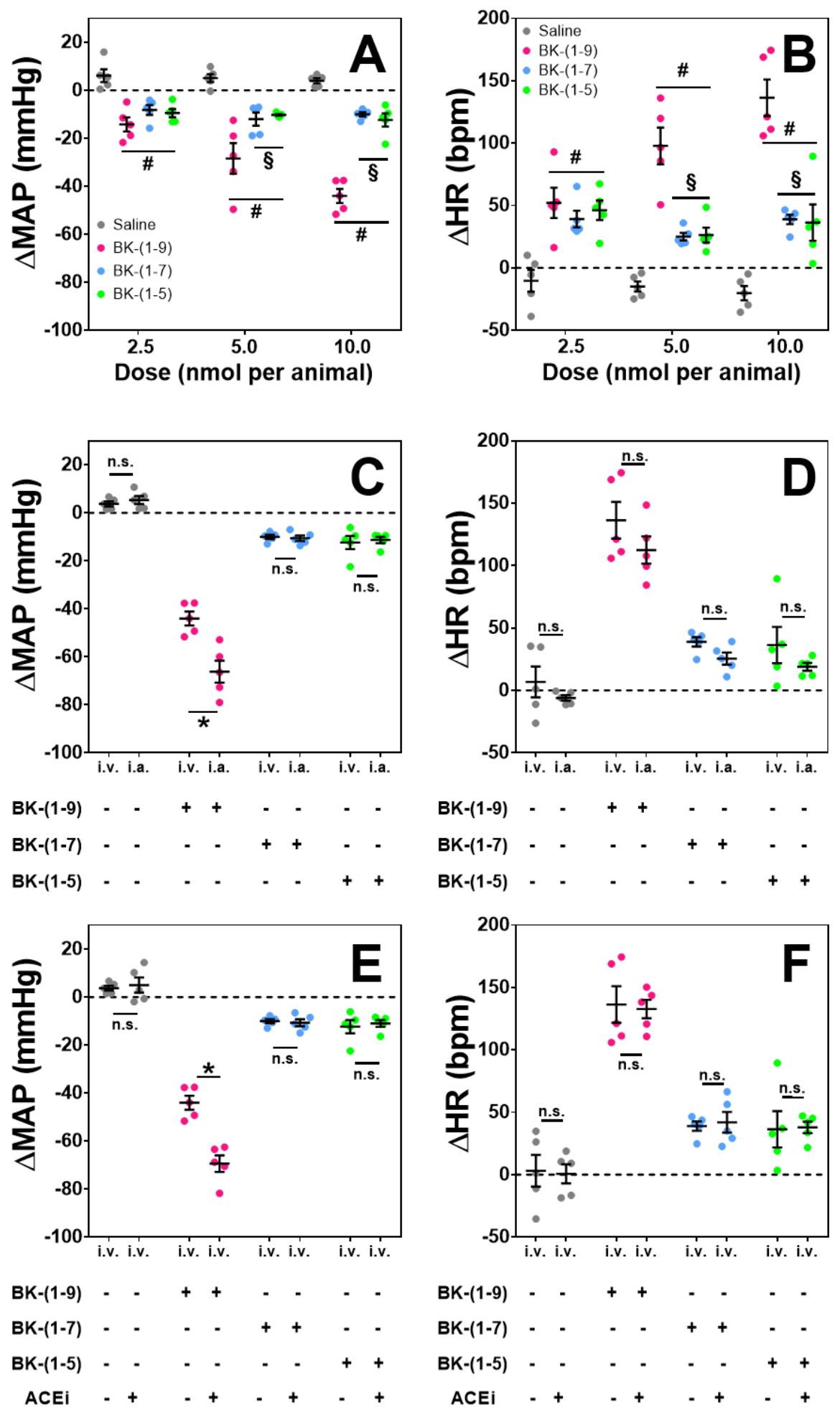

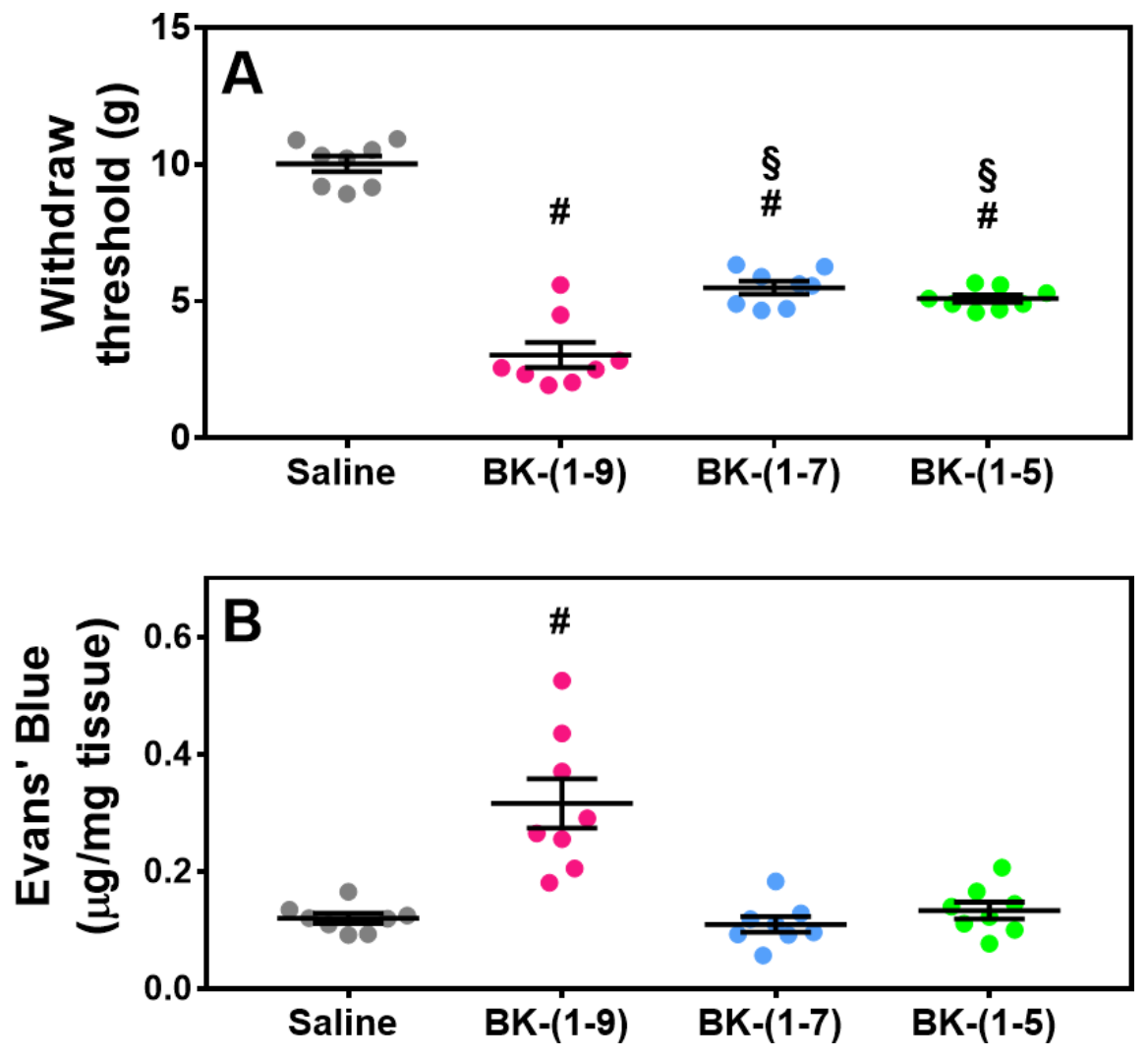